\title{
HASIL BELAJAR MENGANALISIS TEKS NEGOSIASI SISWA KELAS X MAS PROYEK UNIVA MEDAN TAHUN PEMBELAJARAN 2016/2017 (STUDI PERBANDINGAN PENGGUNAAN LKPD DAN PEMBELAJARAN KONVENSIONAL)
}

\section{Oleh}

\author{
Putri Purnama Sari (putripurnamasari216@gmail.com) \\ Dr. Wisman Hadi, M. Hum.
}

\begin{abstract}
ABSTRAK
Penelitian ini bertujuan untuk mengetahui perbedaan hasil belajar menganalisis teks negosiasi antara yang menggunakan LKPD dengan pembelajaran konvensional siswa kelas X MAS Proyek Univa Medan Tahun Pembelajaran 2016/2017. Pengambilan sampel dilakukan secara acak (random sampling), maka diperoleh sampel untuk masing-masing kelas A sebanyak 36 siswa dan kelas B sebanyak 33 siswa. Metode yang digunakan dalam penelitian ini adalah metode eksperimen two group posttest only control design. Instrumen yang digunakan untuk memperoleh data penelitian adalah tes essay. Data yang diperoleh menunjukkan bahwa hasil belajar menganalisis teks negosiasi yang menggunakan LKPD memiliki rata-rata 77.53 berada pada kategori baik sedangkan dengan pembelajaran konvensional rata-rata 57.79berada pada kategori cukup. Pengujian hipotesis $t_{\text {hitung }}=6.71$ kemudian dikonsultasikan pada taraf nyata $\alpha=5 \%$ diperoleh $\mathrm{t}_{\text {tabel }}=2.000$. Karena $t_{\text {hitung }}>t_{\text {tabel }}$ atau $6.71>2.000$, maka hipotesis nihil $\left(\mathrm{H}_{0}\right)$ ditolak. Hal ini membuktikan bahwa ada perbedaan hasil belajar menganalisis teks negosisasi kelas yang menggunakan LKPD dan pembelajaran konvensional siswa kelas X MAS Proyek Univa Medan Tahun Pembelajaran 2016/2017.
\end{abstract}

Kata Kunci : Hasil Belajar, Menganalisis, Teks Negosiasi

\section{PENDAHULUAN}

Pendidikan merupakan suatu usaha untuk membangun negeri, membangkitkan dan mengembangkan sumber daya manusia yang berkualitas dalam era globalisasi saat ini. Melalui pendidikan, akan lahir generasi-generasi yang memiliki modal kuat untuk membangun negeri, melakukan perubahan yang 
berkelanjutan, dan memiliki karakter yang sesuai dengan jati diri bangsa Indonesia.

Mata pelajaran bahasa Indonesia sebagai penghela ilmu pengetahuan memberikan konstribusi besar dalam dunia pendidikan karena melatih siswa untuk aktif baik secara teoritis maupun praktik, berkomunikasi berkomunikasi sebagai bentuk ekspresi, menyampaikan pendapat, dan memperkenalkan diri sendiri dengan empat tahapan pembelajaran di kelas yakni; (1) membangun konteks, (2) permodelan teks, (3) penyusunan teks secara kelompok, dan (4) penyusunan teks secara mandiri pembelajaran bahasa Indonesia yang berbasis teks meghadirkan model pembelajaran yang aktif dan menarik sesuai kurikulum 2103 yang menuntut siswa untuk paham atas materi, aktif dalam diskusi kelas dan kelompok, dan memiliki sikap disiplin dan sopan santun.

Dalam aplikasi kognitif, pembelajaran bahasa Indonesia salah satunya adalah menganalisis. Kegiatan analisis merupakan tingkatan keempat dalam ranah kognitif yang yang terdapat dalam taksonomi Bloom setelah pengetahuan, pemahaman, dan aplikasi. Anggraeni (2016:15) mengemukakan bahwa analisis merupakan kecakapan yang kompleks yang memanfaatkan kecakapan dari ketiga hasil belajar sebelumnya. Dengan kemampuan menganalisis siswa akan mempunyai pemahaman yang komprehensif tentang sesuatu dan dapat memilah atau memecahnya menjadi bagian-bagian yang terpadu, baik dalam hal prosesnya, cara bekerjanya maupun dalam hal sistematikanya. Bila kecakapan analisis telah dikuasai siswa, maka siswa akan dapat mengaplikasikannya dalam situasi baru secara kreatif.

Menganalisis teks negosiasi sesuai dengan silabus edisi revisi tahun 2016 yang terdapat pada KD 3.11 Menganalisis isi, struktur (orientasi, pengajuan, penawaran, persetujuan, penutup) dan kebahasaan teks negosiasi.Pembelajaran menganalisis teks masih tergolong rendah khususnya untuk siswa kelas $\mathrm{X}$ SMA/SMK/MA. Hal ini dapat dibuktikan pada penelitian Pt. Suryani, dkk (2014) yang berjudul "Pembelajaran Bahasa Indonesia Berbasis Teks di kelas X SMA Negeri 1 Singaraja", yang menyatakan bahwa rata-rata nilai yang didapatkan 
siswa hanya berada dalam kategori baik, namun masih berada di bawah KKM 8,00 dan sebab itu siswa yang bersangkutan harus diberikan remedial.

Bernegosiasi merupakan kegiatan berkomunikasi yang selalu terjadi karena seseorang akan melakukan interaksi sosial kepada orang lain yang memiliki kepentingan bersama untuk saling bertukar pikiran mencari penyelesaian bersama. Kosasih (2014:87) mengemukakan, "teks negosiasi tergolong ke dalam bentuk teks diskusi (discussion)." Artinya di dalam teks tersebut membahas isu tertentu yang disertai dengan argumen dari pihak-pihak yang terlibat dengan tujuan untuk mengkompromikan kepentingan yang berbeda. Kosasih (2014:90) juga merumuskan struktur teks negosiasi yaitu pembukaan, isi, dan penutup.

Dalam proses pembelajaran, guru dituntut untuk mempersiapkan bahan ajar atau perangkat pembelajaran yang dapat membantu keberlangsungan proses belajar mengajar. Hal tersebut sesuai dengan penelitian yang dilakukan Sahara (2013) yang berjudul "Perbedaan Hasil Belajar Siswa pada Mata Pelajaran Ekonomi dalam Pembelajaran Menggunakan LKS yang dibeli dengan Pendekatan Konvensional dan LKSyang dibuat Oleh Guru dengan Pendekatan Kontekstual di SMA Negeri 5 Bukittinggi”. Beliau mengemukakan bahwa salah satu bahan ajar yang dapat mengoptimalkan keterlibatan dan keaktifan siswa dalam pembelajaran yaitu lembar kegiatan siswa atau lembar kerja peserta didik dan merupakan salah satu sumber belajar yang meningkatkan hasil belajar siswa.

Nurdin dan Adriantoni (2016:112) mengemukakan, "Lembar Kerja Peserta Didik (LKPD) bisa diartikan lembaran-lembaran yang digunakan peserta didik sebagai pedoman dalam pembelajaran, serta berisi tugas-tugas yang dikerjakan oleh siswa baik berupa soal maupun kegiatan yang akan dilakukan peserta didik." Artinya, LKPD digunakan hanya sebagai pendukung latihan dalam pembelajaran, tidak sebagai pedoman untuk acuan materi pembelajaran. Ditambahkan oleh Sahara (2013:3) dengan adanya LKPD diharapkan juga dapat menciptakan situasi pembelajaran yang dapat memungkinkan siswa untuk lebih banyak mengarahkan dan mengaplikasikan pengetahuannya baik secara personal dan sosial. Sehingga, apa yang telah dipelajarinya dapat dihubungkan dan diterapkan dikehidupannya sehari-hari. 
Pembelajaran konvensional merupakan pembelajaran yang hanya berpusat pada guru dan lazim digunakan oleh guru dalam proses pembelajaran. Artinya, hampir semua kegiatan pembelajaran berlangsung di dominasi oleh guru. Pembelajaran ini umumnya dimulai dengan ceramah dari guru untuk menjelaskan materi yang saat itu dipelajari, lalu diiringi dengan pemberian latihan dan tugas. Hal tersebut tentu tidak mengefektifkan pembelajaran, khususnya pembelajaran menganalisis teks. Hal tersebut didukung dengan penelitian yang dilakukan oleh Banuarli (2012) berjudul "Perbedaan Hasil Belajar Dengan Metode PembelajaranKooperatif Tipe Teams Games Tournament (TGT) danKonvensional dalam Mata Pelajaran Dasar OtomotifSepeda Motor pada Siswa Kelas X Jurusan SepedaMotor di SMK Muhammadiyah 1Bambanglipuro“, beliau mengemukakan bahwa dengan metode konvensional seperti itu akan membentuk kepribadian siswa yang kurang baik, terutama membentuk sikap siswa yang lebih pasif sehingga akan mempengaruhi dalam hasil belajar.

Diungkap oleh Djamarah dan Zain (dalam Sutrisno dan Siswanto, 2016:114) bahwa setiap proses belajar mengajar selalu menghasilkan hasil belajar. Masalah yang dihadapi adalah sampai di tingkat mana hasil belajar yang dicapai. Hal tersebut menggambarkan bahwa yang menjadi fokus bagi guru adalah bagaimana mengelola pembelajaran sehingga dapat mencapai tingkat hasil belajaryang diinginkan.

Menurut Khadijah (2013:80) bahwa "hasil belajar dapat dikatakan tuntas apabila telah memenuhi kriteria ketuntasan minimum yang ditetapkan oleh masing-masing guru guru mata pelajaran”. Berdasarkan pendapat tersebut dapat disimpulkan bahwa hasil belajar untuk kompetensi dasar menganalisis dikatakan tuntas apabila nilai KKM yang ditetapkan oleh guru dapat tuntas dipenuhi siswa.

Selain itu, berdasarkan wawancara yang dilakukan dengan salah satu guru bahasa Indonesia di sekolah MAS Proyek Univa Medan, beliau mengemukakan bahwa hasil belajar menganalisis teks, khususnya siswa kelas $\mathrm{X}$ masih dalam kategori rendah yaitu 75, sementara KKM yang ditetapkan adalah 80. Padahal kompetensi menganalisis merupakan kompetensi yang cukup penting yang harus dituntaskan siswa. 
Berdasarkan uraian di atas dengan melihat beberapa penelitian relevan yang telah dilakukan sebelumnya, maka peneliti tertarik untuk melakukan penelitian dengan membandingkan penggunaan LKPD dengan pembelajaran konvensional. Penelitian ini juga ingin membuktikan bahwa penggunaan LKPD masih layak dijadikan sebagai bahan ajar pendamping dalam proses belajar mengajar, khususnya pada materi menganalisis teks negosiasi.

\section{METODE PENELITIAN}

Dalam suatu penelitian, metode memegang peranan yang sangat penting karena semua kegiatan yang akan dilakukan dalam penelitian tersebut sangat tergantung dengan metode yang digunakan. Metode yang digunakan dalam penelitian ini adalah metode eksperimen. Arikunto (2006:3) mengemukakan bahwa penelitian eksperimen selalu dilakukan dengan maksud untuk melihat akibat suatu perlakuan. Artinya, mencoba meneliti ada tidaknya hubungan sebab akibat atau kausal yang dikenakan pada objek yang diteliti. Dalam penelitian ini ada dua kelompok perlakuan yang berbeda, bertujuan untuk mengetahui perbandingan hasil belajar menganalisis teks negosiasi yang menggunakan LKPD dan pembelajaran konvensional.

Desain penelitian yang digunakan yaitu two group posttest onlycontrol design.Terdapat dua kelompok yang dipilih secara random, kemudian diberikan tes akhir atau posttest. Kelas A merupakan kelas yang menggunakan lembar kerja peserta didik (LKPD)sedangkan kelas B merupakan kelas dengan pembelajaran konvensional.Kedua kelas tersebut akan diberi posttest (tes akhir) untuk melihat perbedaan hasil belajar menganalisis teks negosiasi antara kedua kelas yang menggunakanlembar kerja peserta didik (LKPD) dengan kelas pembelajaran konvensional. 
Tabel 1. Desain Penelitian

\begin{tabular}{|l|c|c|}
\hline \multicolumn{1}{|c|}{ Kelas } & Perlakuan & Posttest \\
\hline $\begin{array}{l}\text { X-MIA 1 Kelas A } \\
\text { (Menggunakan LKPD) }\end{array}$ & $\mathrm{X}_{1}$ & $\mathrm{O}_{1}$ \\
\hline $\begin{array}{l}\text { X-IIA 1 Kelas B } \\
\text { (Pembelajaran Konvensional) }\end{array}$ & $\mathrm{X}_{2}$ & $\mathrm{O}_{2}$ \\
\hline
\end{tabular}

Keterangan:

$\mathrm{X}_{1}$ : pembelajaran menganalisis teks negosiasi dengan menggunakan lembar kerja peserta didik (LKPD) di kelas A

$\mathrm{O}_{1} \quad$ : posttest (tes akhir) di kelas A

$\mathrm{X}_{2}$ : pembelajaran menganalisis teks negosiasi dengan pembelajaaran konvensional di kelas B

$\mathrm{O}_{2}$ : posttest (tes akhir) di kelas $\mathrm{B}$

\section{HASIL PENELITIAN DAN PEMBAHASAN}

\section{Hasil Belajar Menganalisis Teks Negosiasi dengan Menggunakan LKPD Siswa Kelas X MAS Proyek Univa Medan Tahun Pembelajaran 2016/2017}

Berdasarkan data yang diperoleh dari hasil belajar menganalisis teks negosiasi dengan menggunakan LKPD siswa kelas X MAS Proyek Univa Medan diperoleh rata-rata 77.53 dengan nilai tertinggi 100 dan nilai terendah 60. Aspek penilaian meliputi isi, struktur, dan ciri kebahasaan teks negosiasi. Siswa mampu mencapai skor yang ditetapkan pada setiap aspek-aspek yang ditentukan dan dapat dikatakan bahwa hasil belajar menganalisis teks negosiasi siswa di kelas yang menggunakan LKPD berada pada kategori baik. Hal tersebut karena penggunaan LKPD dalam pembelajaran membantu dan memudahkan siswa dalam menguasai materi menganalisis teks negosiasi karena dilengkapi beberapa contoh teks negosiasi. 
2. Hasil Belajar Menganalisis Teks Negosiasi dengan Menggunakan Pembelajaran Konvensional Siswa Kelas X MAS Proyek Univa Medan Tahun Pembelajaran 2016/2017

Berdasarkan data yang diperoleh dari hasil belajar menganalisis teks negosiasi dengan pembelajaran konvensional diperoleh rata-rata 57.79 dengan nilai tertinggi 82 dan nilai terendah 43. Hasil belajar yang diperoleh di kelas dengan pembelajaran konvensional berada pada kategori cukup karena pembelajaran didominasi dengan ceramah tanpa ada bahan ajar pendukung dalam proses belajar mengajar.

3. Perbedaan Hasil Belajar Menganalisis Teks Negosiasi yang Menggunakan LKPD dengan Pembelajaran Konvensional Siswa Kelas X MAS Proyek Univa Medan Tahun Pembelajaran 2016/2017

Perbedaan hasil belajar menganalisis teks negosiasi siswa kelas X MAS Proyek Univa Medan memperlihatkan perbedaan rata-rata yang diperoleh dari kedua kelas. Untuk lebih jelas dapat dilihat pada tabel berikut.

Tabel 2. Perbedaan Hasil Belajar Kedua Kelas

\begin{tabular}{|l|c|c|}
\hline & $\begin{array}{c}\text { Kelas yang } \\
\text { menggunakan LKPD }\end{array}$ & $\begin{array}{c}\text { Kelas dengan pembelajaran } \\
\text { konvensional }\end{array}$ \\
\hline Rata-rata & $\mathbf{7 7 . 5 3}$ & $\mathbf{5 7 . 7 9}$ \\
\hline Nilai Tertinggi & 100 & 82 \\
\hline Nilai Terendah & 60 & 43 \\
\hline Varians & 166.20 & 132.80 \\
\hline Standar Deviasi & 12.89 & 11.52 \\
\hline
\end{tabular}

Berdasarkan tabel 2 dapat disimpulkan bahwa terdapat perbedaan hasil belajar menganalisis teks negosiasi siswa kelas X MAS Proyek Univa Medan Tahun Pembelajaran 2016/2017 antara kelas yang menggunakan LKPD dengan kelas pembelajaran konvensional. 
Selanjutnya uji normalitas untuk mengetahui apakah populasi penelitian telah berdistribusi normal maka digunakan uji Liliefors dengan ketentuan jika $\mathrm{L}_{\text {hitung }}<\mathrm{L}_{\text {tabel }}$ pada taraf $\alpha=5 \%$ maka data hasil belajar menganalisis teks negosiasi berdistribusi normal.

Tabel 3. Uji Normalitas

\begin{tabular}{|l|c|c|c|}
\hline \multicolumn{1}{|c|}{ Kelas } & $\mathbf{L}_{\text {hitung }}$ & $\mathbf{L}_{\text {tabel }}$ & Kesimpulan \\
\hline $\begin{array}{l}\text { Kelas A yang Menggunakan } \\
\text { LKPD }\end{array}$ & 0.137 & 0.148 & Normal \\
\hline $\begin{array}{l}\text { Kelas B dengan } \\
\text { Pembelajaran Konvensional }\end{array}$ & 0.143 & 0.154 & Normal \\
\hline
\end{tabular}

Hasil uji normalitas dari kelas yang menggunakan LKPD yaitu 0.137 < 0.148 sedangkan kelas dengan pembelajaran konvensional $0.143<0.154$, artinya dari kedua kelas $\mathrm{L}_{\text {hitung }}$ yang diperoleh lebih kecil dari $\mathrm{L}_{\text {tabel }}$ membuktikan bahwa sebaran data hasil belajar menganalisis teks negosiasi berdistribusi normal, baik kelas yang menggunakan LKPD maupun kelas dengan pembelajaran konvensional.

Uji homogenitas dilakukan dengan tujuan untuk mengetahui sampel yang dijadikan dalam penelitian memiliki varians yang homogen atau tidak. Uji homogenitas dilakukan dengan uji $\mathrm{F}$ dengan ketentuan jika $\mathrm{F}_{\text {hitung }}<\mathrm{F}_{\text {tabel }}$ pada taraf $\alpha=5 \%$ maka kedua tersebut homogen. Selanjutnya diperoleh $\mathrm{F}_{\text {hitung }}=1.252$ dan $\mathrm{F}_{\text {tabel }}=1.757$, kemudian dikonsultasikan pada tabel nilai kritis distribusi $\mathrm{F}$ dengan dk penyebut 35 dan dk pembilang 33. Jadi $F_{\text {hitung }}<F_{\text {tabel }}$ yakni $1.252<1757$. Hal tersebut membuktikan bahwa sampel kedua varians berasal dari populasi yang homogen.

Setelah uji normalitas dan homogenitas dilakukan, maka untuk dapat membuktikan hipotesis apakah terdapat perbedaan antara kelas yang menggunakan LKPD dengan kelas pembelajaran konvensional digunakan uji ttest menurut Sugiono (2016:192). 
Tabel 4. Uji Hipotesis

\begin{tabular}{|l|c|c|c|c|c|}
\hline \multicolumn{1}{|c|}{ Kelas } & $\mathbf{N}$ & $\overline{\boldsymbol{X}}$ & $\boldsymbol{S}^{\mathbf{2}}$ & $\mathbf{t}_{\text {hitung }}$ & $\mathbf{t}_{\text {tabel }}$ \\
\cline { 1 - 4 } $\begin{array}{l}\text { Kelas A yang menggunakan } \\
\text { LKPD }\end{array}$ & 36 & 77.53 & 166.20 & \multirow{2}{*}{6.71} & 2.000 \\
\cline { 1 - 1 } $\begin{array}{l}\text { Kelas B dengan } \\
\text { Pembelajaran Konvensional }\end{array}$ & 33 & 57.79 & 132.80 & & \\
\hline
\end{tabular}

Setelah t diketahui, kemudian dikonsultasikan dengan tabel t pada taraf signifikan 5\% dengan $\mathrm{dk}=\mathrm{n}_{1}+\mathrm{n}_{2}-2=36+33-2=67$. Dari 67 diperoleh $\mathrm{t}_{\text {tabel }}=$ 2.000. Karena $t_{\text {hitung }}$ yang diperoleh lebih besar dari $t_{\text {tabel }}$ yaitu $6.71>2.000$, maka hipotesis nol $\left(\mathrm{H}_{0}\right)$ ditolak dan hipotesis alternatif $\left(\mathrm{H}_{\mathrm{a}}\right)$ diterima. Hal ini membuktikan bahwa ada perbedaan hasil belajar menganalisis teks negosiasi antara yang menggunakan LKPD dengan pembelajaran konvensional. Hasil belajar di kelas yang menggunakan LKPD lebih tinggi dibandingkan dengan kelas pembelajaran konvensional, dengan rata-rata 77.53 di kelas yang menggunakan LKPD menunjukkan rata-rata lebih tinggi daripada rata-rata 57.79 di kelas dengan pembelajaran konvensional.

LKPD memberikan kemudahan bagi guru dan siswa dalam proses pembelajaran. Seperti yang diungkapkan Bukarewa dan Sabariman (2015:149) bahwa LKPD memudahkan guru dalam melaksanakan pembelajaran, sedangkan siswa lebih mudah memahami suatu materi dengan menyajian tugas-tugas yang dapat melatih kemandirian siswa sehingga menimbulkan rasa tanggung jawab bagi siswa untuk menyelesaikannya. Artinya, dengan LKPD siswa mampu belajar secara mandiri dan berdiskusi dalam kelompok, dengan arahan dan perhatian besar yang diberikan oleh guru terhadap hasil pekerjaan siswa dalam LKPD. Sedangkan pembelajaran konvensional menurut Kresma (2014:155) dilakukan dengan guru memberikan apersepsi dilanjutkan dengan memberikan materi secara verbal dengan contoh-contoh dan membuka sesi tanya jawab kemudian pemberian tugas.

Dengan demikian pembelajaran menganalisis teks negosiasi tidak akan berjalan efektif dan memudahkan siswa menguraikan serta menjabarkan isi, struktur, dan ciri kebahasaan teks hanya dengan penjelasan verbal saja, tanya 
jawab lalu diberikan tugas. Tetapi dengan bahan ajar cetak seperti LKPD dapat membantu siswa belajar secara mandiri atau kelompok dalam menganalisis teks negosiasi untuk menjabarkan dan menguraikan isi, struktur, dan ciri kebahasaan teks negosiasi. Jadi LKPD membantu siswa untuk lebih mudah dan mampu dalam memenuhi ranah kognitif keempat yaitu analisis, terkhusus menganalisis teks negosiasi meliputi isi, struktur, dan ciri kebahasaan teks negosiasi.

\section{PENUTUP}

Berdasarkan hasil penelitian dan pembahasan yang telah diuraikan pada pembahasan di atas, maka dapat disimpulkan bahwa hasil belajar menganalisis teks negosiasi siswa kelas X MAS Proyek Univa Medan Tahun Pembelajaran 2016/2017 dengan menggunakan LKPD termasuk dalam kategori baik dengan rata-rata 77.53 dengan nilai tertinggi 100 dan terendah 60, dan standar deviasi 12.89 sedangkan dengan pembelajaran konvensionaltermasuk dalam kategoricukup dengan rata-rata 57.79 dengan nilai tertinggi 82 dan terendah 43 , dan standar deviasi 11.52.t $\mathrm{t}_{\text {hitung }}$ yang diperoleh lebih besar dari $\mathrm{t}_{\text {tabel }}$ yang dikonsultasikan pada taraf nyata $\alpha=0.05$ atau 5\% yaitu $6.71>2.000$. Maka hipotesis nol $\left(\mathrm{H}_{0}\right)$ ditolak dan hipotesis alternatif $\left(\mathrm{H}_{\mathrm{a}}\right)$ diterima. Artinya ada perbedaan hasil belajar menganalisis teks negosiasi antara yang menggunakan LKPD dan pembelajaran konvensional siswa kelas X MAS Proyek Univa Medan Tahun Pembelajaran 2016/2017.

\section{DAFTAR PUSTAKA}

Anggraeni, Ferti. 2016. Perbandingan Hasil Belajar Menggunakan LKS Berbasis Laboratorium Virtual dengan LKS Konvensional Materi Optik Fisis.Skripsi. FKIP Universitas Lampung: Bandar Lampung.

Arikunto, Suharsimi. 2006. Prosedur Penelitian Suatu Pendekatan Praktis. Jakarta: Rhineka Cipta.

Banuarli, Alfian. 2012. Perbedaan Hasil Belajar dengan Metode Pembelajaran Kooperatif Tipe Teams Games Tournament (TGT) dan Konvensional dalam Mata Pelajaran Dasar Otomotif Sepeda Motor pada Siswa Kelas X 
Jurusan Sepeda Motor di SMK Muhammadiyah 1 Bambanglipuro. Skripsi. UNY: Prodi Pendidikan Teknik Otomotif.

Bukarewa dan Sabariman. 2015. Perbandingan Hasil Belajar Siswa Antara Model Pembelajaran Langsung dengan LKS dan Pembelajaran Konvensional Mekanika Teknik Kelas X SMK Negeri 1 Sidoarjo. Jurnal Kajian Pendidikan Teknik Bangunan, Vol. 3, No. 3, 147-156. Surabaya: Jurusan Teknik Sipil UNS.

Khadijah. 2013. Belajar dan Pembelajaran. Bandung: Citapustaka Media.

Kosasih, E. 2014. Jenis-Jenis Teks. Bandung: Yrama Widya.

Kresma, Eka Nella. 2014. Perbandingan Pembelajaran Konvensional dan Pembelajaran Berbasis Masalah terhadap Titik Jenuh Siswa Maupun Hasil Belajar Siswa dalam Pembelajaran Matematika. Educatio Vitae, Vol. 1, Tahun 2014, 152-164. Madium: FKIP Universitas Katholik Widya Mandala.

Nurdin, Syafruddin dan Adriantoni. 2016. Kurikulum dan Pembelajaran. Jakarta: Rajawali Pers.

Sahara. 2013. Perbedaan Hasil Belajar Siswa Pada Mata Pelajaran Ekonomidalam Pembelajaran Menggunakan LKS yang dibeli dengan Pendekatan Konvensional dan LKS yang dibuat Oleh Guru dengan Pendekatan Kontekstual di SMA NEGERI 5 Bukit Tinggi. Padang: Fakultas Ekonomi UNP.

Sugiono. 2016. Metode Penelitian Pendidikan Pendekatan Kuantitatif, Kualitatif, dan $R \& D$. Bandung: Alfabeta.

Suryani, Pt, dkk. 2014. Pembelajaran Bahasa Indonesia Berbasis Teks di Kelas X SMA Negeri 1 Singaraja. E-Jurnal Pendidikan Bahasa dan Sastra Indonesia. Vol. 2, No. 1 Tahun 2014, 1-13.

Sutrisno dan Siswanto. 2016. Faktor-faktor yang Mempengaruhi Hasil Belajar Siswa pada Pembelajaran Praktik Kelistrikan Otomotif SMK di Kota Yogyakarta. Jurnal Pendidikan Vokasi. Volume 6, No 1, Februari 2016, 111120. 